AUTHOR:

Prof O. Lokshyna ${ }^{1}$

Prof O. Topuzov ${ }^{1}$

AFFILIATION:

${ }^{1}$ Institute of Pedagogy of the

National Academy of Educational

Sciences of Ukraine, Ukraine

DOI: http://dx.doi.

org/10.18820/2519593X/pie.v39.

i1.13

e-ISSN 2519-593X

Perspectives in Education

2021 39(1): 207-230

PUBLISHED:

12 March 2021

RECEIVED:

10 November 2020

ACCEPTED:

5 February 2021

\section{COVID-19 AND EDUCATION IN UKRAINE: RESPONSES FROM THE AUTHORITIES AND OPINIONS OF EDUCATORS}

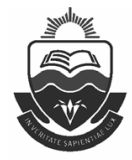

Published by the UFS

http://journals.ufs.ac.za/index.php/pie

(๑) Creative Commons

With Attribution (CC-BY)

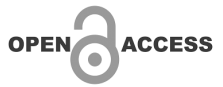

\section{ABSTRACT}

The COVID-19 pandemic, which struck the world in 2020, has hit education systems around the world. The world community has begun searching for and testing models for organising the educational process in a new reality. The purpose of this study was to analyse how the education system in Ukraine is functioning under the COVID-19 pandemic. The theoretical framework for considering the research problem is based on the theory of synergetics. Such synergetic postulates as openness, evolution, dynamics, bifurcation point, interaction, self-organisation, irreversibility and new state are key guidelines for understanding the processes taking place in Ukrainian education. A qualitative research approach was used to guide the study. The research methods included the review of the governmental documents, review of the surveys and interviews. The major finding is that the COVID-19 pandemic is transforming the education system in Ukraine and many changes are positive. This includes the long-awaited autonomy of educational institutions, the opportunity to acquire digital skills by educators, strengthening cooperation with regional and local authorities and updates to the overloaded curriculum. The Ukrainian authorities, the pedagogical community and society are working together to organise education under new conditions. However, Ukrainian education faces serious challenges (partly inadequate Internet access in homes, especially in rural areas; lack of educators' online instruction skills; few official methodological guidelines and online textbooks and low levels of motivation of students to participate in online sessions). The findings thus revealed the importance of a national strategy for the development of education, considering the recommendations of the international organisations and the experience of foreign countries.

Keywords: COVID-19; education; Ukraine; challenges; quality of education; equal access to education.

\section{INTRODUCTION}

Since the beginning of 2020, COVID-19 has covered the world. The COVID-19 breakdown is characterised by speed and scale. According to the World Health Organization (WHO) from January to October 2020, 40455651 people fell ill with COVID-19 while 1119431 passed away (WHO, 2020). The established order of human life was destroyed; transformations affected all spheres of life, including education. 
To prevent the outbreak of COVID-19 among children and youth, countries have closed educational institutions using different approaches depending on the dynamics and scale of the disease. According to UNESCO monitoring, over 100 countries have implemented nationwide closures, affecting over half of the world's student population as of the end of March 2020 (UNESCO, 2020a). In parallel with the closures, countries started to search for and develop efficient tools for organising education under the new reality. Considering the recommendations of the international organisations (WHO, UNESCO, OECD, etc.) and depending on the national policies, various approaches were introduced.

Ukraine, similar to other countries, began to respond to the COVID-19 challenges. On 11 March 2020, the Cabinet of Ministers of Ukraine adopted the Resolution No. 211 that introduced the nationwide lockdown in Ukraine (Cabinet of Ministers of Ukraine, 2020a). The Resolution prohibited the attendance of educational institutions of all levels (preschool, secondary, VET, non-tertiary, tertiary) and types (state, municipal, private) starting from 12 March 2020. Thus, the lockdown of education in Ukraine took place. The transformation of the education system to adapt to the new conditions had begun.

The purpose of the present study was to analyse how the education system in Ukraine is functioning under the COVID-19 pandemic. In pursuit of this purpose, the following objectives have been developed:

- to examine the character of the education policy in Ukraine under the COVID-19 pandemic; and

- to identify achievements and challenges in the organisation of education faced by educational institutions.

The following research questions have been formulated to achieve the aim and objectives:

- What is the educational policy under the COVID-19 pandemic in Ukraine?

- What is the practice of organising education by educational institutions under the COVID-19 pandemic?

The central idea presented in this paper is that the COVID-19 pandemic is transforming the education system in Ukraine. The Ukrainian authorities, the pedagogical community and society are working together to organise education under the new conditions. The theoretical framework for considering the research problem is based on the theory of synergetics. Such synergetic postulates as openness, evolution, dynamics, bifurcation point, interaction, selforganisation, irreversibility and new state are key guidelines for understanding the processes taking place in Ukrainian education. The literature and the official documents in the field of the Ukrainian education system functioning under the COVID-19 pandemic are highlighted. The study provides an aggregated view of educators, students and parents' perception of the practice of organising instruction by educational institutions under the COVID-19 pandemic. The contribution this study makes is that it shows despite the efforts of the educational authorities, Ukrainian education faces serious challenges. This is evidenced by the opinion of stakeholders. The prospect here is the implementation of a national strategy for the development of education under new conditions, considering the recommendations of the international organisations and the experience of foreign countries. Changes should address all aspects - organisation of instruction, curriculum and assessment technologies. Equal access to education and high quality of education are to be key guidelines of the strategy. 


\section{REVIEW OF RELATED LITERATURE}

Given the novelty of the COVID-19 pandemic, research on its impact on education is ongoing. A wide range of issues are being explored, including organising distance learning, reopening educational institutions after lockdown, ensuring equal access to education, improving the skills of teachers, adapting the curriculum to new formats and motivating students to learn. The studies on the impact of COVID-19 on education as a holistic system are particularly relevant for this study. According to Daniel (2020) education authorities and institutions had very little time to prepare for a remote-teaching regime while Tadesse and Muluye (2020) postulate about the serious impact of the pandemic on education in developing countries. They primarily emphasise challenges such as the lack of ICT infrastructures, computers, radio and television. The poor and digitally illiterate families are suffering more in this situation and this increases inequality. Based on the position of synergetics, we share the vision of a pandemic through a prism of prospects for education. We agree with Fullan (2020), who argues that there is nothing so complex to solve than the situation we have in present times. At the same time, the pandemic has also provided opportunities to make changes.

A holistic vision of the education functioning under the pandemic is provided in numerous reports of the international organisations. The Organisation for Economic Co-operation and Development (OECD) Report titled A Framework to guide an education response to the COVID-19 Pandemic of 2020 was the first document from an international organisation on the COVID-19 pandemic, which, with the permission from its authors, was translated into the Ukrainian language by the National Academy of Educational Sciences of Ukraine (NAES) and disseminated by the Ministry of Education and Sciences of Ukraine (MES) among governmental authorities and educational institutions. The ideas on the priorities to respond the pandemic served as a valuable guide for the authors of the manuscript when developing recommendations.

Wolhuter (2020) writes about the potential of comparative education studies under the pandemic. Comparative and international education gets an opportunity to prove its value to the world of praxis (that is praxis at the levels of education in education institutions and at the level of planning and reform of education at education system level). Lokshyna et al. (2020) have generalised the practices of distance learning (selection of e-resources, designing national learning platforms, providing technical assistance) as well as the algorithm of educational institutions reopening in different countries. The report contains recommendations of the international organisations for the national governments on the organisation of education under COVID-19 - how to mitigate the impact of educational institutional closures and facilitating the continuity of education for all through distance learning.

The analytical report authored by Hrynevych et al. (2020) highlights the experience of the countries in organisation of distance learning and the challenges of legal and technological nature accompanying the functioning of schools during lockdown in Ukraine (the obsolescence of regulations governing distance learning, unregulated employment of teachers, the problems with access to broadband Internet and digital gadgets and the lack of a single national educational platform). The authors proposed recommendations for the organisation of education in schools during the adaptive lockdown. A systematic vision of the challenges in schools under lockdown has become a valuable source for writing this paper. 


\section{THEORETICAL FRAMEWORK}

Synergy can be defined in a broad sense as a combined action or operation (Meriam-Webster); a combined or cooperative action or force (Collins Dictionary).

The scientific literature on synergetics suggests that the synergy is an interdisciplinary science grounding the self-organisation of structures of open systems in the process of evolution. This view is based on the ideas of Haken (1983) who defined the synergy effect when the joint actions cause the emergence of new qualities/values.

The following key features of the synergy substantiated by Benecke, Schurink and Roodt (2007:9) are especially important for our research:

- it is systemic and hence should be viewed in the context of processes;

- ...units working together will generate greater value than they would by working apart;

- it is the result of a process whereby better use of physical and invisible resources is made by viewing the total diversified organisation as one system.

Kremen (2013), developing the concept of pedagogical synergetics, writes that it gives an opportunity to take a new approach to the development of the challenges of education systems, considering them primarily from the standpoint of openness, co-creation and it focuses on self-development. He underlines that in the pedagogical process the emergence of new, stronger structures that have new qualities becomes possible if the old system is in crisis and its former structures do not meet the requirements of the new situation.

Synergetic discourse has creative potential for this study. The synergetics idea of the openness of a system to external influences is important. The COVID-19 pandemic is considered as an external influence that leads to the transformation of the education system generating new qualities corresponding to the new situation. Synergetic ideas about instability and nonlinearity were used for the consideration of the education system under the pandemic from the standpoint of multivariability and optionality (lack of unified approaches to the organisation of instruction in educational institutions, the possibility of choosing communication channels and the existence of learning options/model under adaptive quarantine). The concept of bifurcation is interpreted by synergetics not as a point of transition from one state to another, but as a transition zone/relatively independent time. This concept provides a better understanding of the processes at each stage (national/adaptive lockdown). The thesis of synergetics on selforganisation under the influence of social energy required an analysis of public consciousness and pedagogical thinking (the attitude of parents and teachers to distance learning). The thesis of irreversibility actualises the position of the authors of the study on the need to develop a new strategy for the development of national education.

\section{RESEARCH DESIGN AND METHODOLOGY}

The time frame of the research covers March-October 2020. From March to May 2020 (2019/2020 academic year) educational institutions were closed all over the country and distance learning was introduced. The 2020/2021 academic year started during the adaptive lockdown in September 2020. The adaptive lockdown provides application of quarantine measures depending on the pandemic situation in a region or in an administrative-territorial unit. The adaptive lockdown has introduced "green", "yellow", "orange" or "red" COVID-19 epidemic levels of danger (Cabinet of Ministers of Ukraine, 2020b). In these conditions, a 
blended education model has been introduced that envisages a combination of face-to-face (in-class) and distance (online) learning. Different formats of the education organisation in March-May and in September-October 2020 have determined the logic of the research. Based on the governmental documents, the organisation of education in the period of the national lockdown and in the period of adaptive lockdown is analysed separately. At the same time, the challenges formulated by the authors are common to both periods.

The present study was based on a qualitative research design. Three data collection methods were used. These methods included the review of the governmental documents, review of the surveys based on a quantitative analysis and interviews. The review of the governmental documents was employed to study the regulatory support of the education system functioning under COVID-19. The official documents determining the organisation of the educational process at ISCED 1-5 levels have been studied. These are resolutions, orders and letters of the Cabinet of Ministers of Ukraine, the Ministry of Health of Ukraine and the Ministry of Education and Science of Ukraine. The key criterion for selecting documents was the time of their adoption. The documents adopted during the pandemic, starting from 11 March 2020 were selected for the analysis. In Ukraine, the MES is the central executive body that ensures the formation and implementation of the state policy in the field of education. Therefore, the documents approved by the MES constitute the main array of documents analysed in the manuscript. Authenticity was another criterion for selecting documents. Only documents posted on the official portal of the Parliament (Verkhovna Rada) of Ukraine (https:// www.rada.gov.ua/) and on the site of the MES (https://mon.gov.ua/ua) have been selected for the analysis. The aim of this review was to ascertain whether the educational policy in the conditions of a pandemic corresponds to the new realities. The education policy is understood in this study as the collection of laws/rules that govern the operation of an education system. Considering thematic analysis as an umbrella method for analysing qualitative data, identifying key themes in the government documents was essential.

The review of the surveys was employed to explore the perceptions of educators, students and parents on organisation of instruction in the educational institutions under the COVID-19 pandemic. Three criteria were used to select the surveys. These were wide geographical coverage, number of respondents and the reliability of the source. The following large-scale surveys of the governmental institutions covering various regions of Ukraine and representing the views of different stakeholders have been used as data for the research:

- "Educating Children during Lockdown" by the Educational Ombudsman Service. This is an All-Ukrainian non-representative online survey conducted from 8-13 April 2020. The target population was parents of secondary school students. Eight thousand and fifty-six responses have been received (Educational Ombudsman Service in Ukraine, 2020).

- "Organisation of Distance Learning in General Secondary Education Institutions under Lockdown" by the State Service of Education Quality of Ukraine. This is an All-Ukrainian non-representative online survey conducted from 8-15 April 2020. The target population was secondary school principals, teachers, parents and students from grade 8 to 11. Two hundred and eleven thousand nine hundred respondents took part in the survey, including 120500 parents, 44100 students, 43400 teachers and 3900 school principals (State Service of Education Quality of Ukraine, 2020a).

"Use of Distance Learning Technologies in Higher Education Institutions of Ukraine" by the State Service of Education Quality of Ukraine. This online survey was conducted from 23 April until 5 May 2020. The target population was students and faculty of higher education institutions. A total of 28391 
respondents took part in the survey, i.e. 22367 students and 6024 faculty (State Service of Education Quality of Ukraine, 2020b).

"Readiness of Schools to Organize the Educational Process under COVID-19 Pandemic" by the state scientific institution "The Institute of Educational Analytics" under the MES jointly with UNICEF. This is a non-representative online survey conducted at the beginning of July 2020. The target population was secondary school principals. In total, 10175 school principals took part in the survey $(67.4 \%$ of the total number of school principals of Ukraine) of which $65 \%$ are principals of rural schools and $35 \%$ of urban schools (Ministry of Education and Science of Ukraine, 2020a).

The "Digital Literacy of the Population of Ukraine" 2019 survey by the Ministry of Digital Transformation of Ukraine has been used to obtain data on the access of the population of Ukraine to digital tools and the Internet. One thousand eight hundred adults aged 18-70 and 859 young people aged 10-17 have been interviewed. Sample type: stratified quota (Ministry of Digital Transformation of Ukraine, 2019).

Each survey reveals a separate aspect of the organisation of training under the pandemic, which in general provides a holistic picture of education functioning. Each survey was analysed qualitatively using the research question "What is the practice of organising education by educational institutions under the COVID-19 pandemic?" We looked for evidence of organisation of distance learning and blended learning in the educational institution of ISCED 1-5 levels. Based on the topics identified during the analysis of the governmental documents, the surveys were analysed according to the following parameters: use of time table for distance learning, distance usage/communication tools, assessment of academic achievements, Internet access and availability of computers at home.

The interviews were conducted online at the end of October 2020. The interview guide included information about the educational institution and questions regarding the organisation of the instruction. The aim of the interviews was to study the instruction formats during the adaptive lockdown on the example of secondary education institutions. The interviews were transcribed verbatim while the interview data were summarised and organised into themes (instruction model, organisation of education, curriculum, challenges) to obtain answers to the research question. K. Spitkovska, the principal of the secondary education institution (ISCED levels 1-3) "Gymnasium No. 107 "Vvedenska" of the city of Kyiv, and T. Yermak, the principal of the secondary education institution (ISCED levels 1-3) "Educational Complex - Lyceum No. 157" of Kyiv have been interviewed. These schools are experimental institutions of the Institute of Pedagogy of the NAES of Ukraine, cooperation agreements have been signed with them and the principals of these schools are graduate students of the Institute. All ethics related issues were observed, including participants' consent to record their answers and to publish the findings of the interviews.

\section{RESULTS}

The coronavirus disease outbreak in Ukraine and the governmental response to it allows for two periods of the "COVID-19 time" in the education of Ukraine:

- The period of the nationwide lockdown of education: the end of the 2019/2020 academic year (March-May); and

- The period of the adaptive lockdown of education: the beginning of the 2020/2021 academic year (September-October). 


\subsection{The period of the nationwide lockdown of education}

The nationwide lockdown of educational institutions required the authorities to propose a new education format. To this end, the MES has approved the following documents:

- Letter of the MES No. 1/9-154 of 11 March 2020, in which the MES recommends the local education authorities and heads of educational institutions to develop measures ensuring instruction by using distance learning tools, as well as to ensure preventive epidemiological measures (Ministry of Education and Science of Ukraine, 2020b);

- Order of the MES No. 392 of 12 March 2020 "On ensuring the implementation of preventive and anti-epidemic measures" in which the MES orders the local educational authorities and heads of educational institutions to organise the educational process in the distance learning format in accordance with the Regulation of the MES "On Distance Learning" adopted on 25 April 2013 (Ministry of Education and Science of Ukraine, 2020c);

- Letter of the MES No.1/9-161 of 13 March 2020 on the organisation of remuneration of employees of educational institutions during COVID-19 lockdown in which the MES stresses that in accordance with the Labour Code of Ukraine, the average salary is guaranteed in emergency situations (Ministry of Education and Science of Ukraine, 2020d);

- Order of the MES No. 406 of 16 March 2020 "On organizational measures to prevent the outbreak of COVID-19", in which MES orders the heads of educational institutions to ensure the implementation of educational programmes under lockdown by using the distance learning tools as well as by introducing flexible (remote) working hours for employees of educational institutions (Ministry of Education and Science of Ukraine, 2020e);

- Letter of the MES No. 1/9-173 of 23 March 2020 on the organisation of the educational process in general secondary education institutions (ISCED levels 1-3) during lockdown (Ministry of Education and Science of Ukraine, 2020f);

- Letter of the MES No. 1/9-176 of 25 March 2020 on the organisation of the educational process in short-cycle tertiary education institutions (ISCED level 5) during lockdown (Ministry of Education and Science of Ukraine, 2020g);

- Letter of the MES No. 1/9-177 of 26 March 20 on the organisation of the educational process in vocational educational institutions (post-secondary non-tertiary education - ESCED level 4) during lockdown (Ministry of Education and Science of Ukraine, 2020h); and

- Letter of the MES No. 1/9-178 of 27 March 2020 on the ending the 2019/2020 academic year in the education institutions of secondary, non-tertiary and tertiary education (Ministry of Education and Science of Ukraine, 2020i).

On 15 April 2020 MES launched a special website aimed at informing the stakeholders on the peculiarities of the organisation of education in Ukraine under COVID-19 (Ministry of Education and Science of Ukraine, 2020j).

Thus, in a short time (actually during March), MES developed general regulations for the operation of educational institutions under lockdown. MES has defined a standard format of the organisation of instruction for the ISCED levels 1-3 and 4 institutions. In particular, it has regulated the structure of the 2019/2020 academic year, technologies of "fixation" of the educational process (in class books, student diaries, etc.), assessment of students' academic achievements, etc. 
The MES has proposed an indicative format for tertiary education institutions that are autonomous in Ukraine. It has covered issues of the workload of faculty, distance organisation of lectures/seminars/practicums, access of students to educational resources, feedback between students and lecturers, management and monitoring of educational process, etc.

As evidenced by the surveys the declared by the authorities, distance learning has been implemented by educational institutions. Figure 1 shows that almost $90 \%$ of parents testified that their children continued studying during the nationwide lockdown (Educational Ombudsmen Service in Ukraine, 2020).

- Yes

- No

- Partially

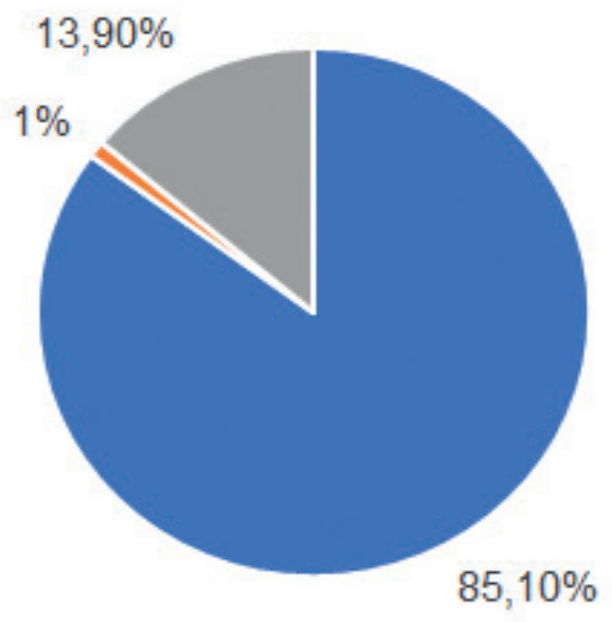

Figure 1. Percentage distribution of the responses of parents to the question "Did your child continue studying during the nationwide lockdown?"

For their part, almost $100 \%$ of school principals answered that their schools switched to the distance format of instruction. In response to the question, "Did distance learning take place during the nationwide lockdown in your institution?". $96.9 \%$ of school principals responded yes in the survey of the State Service of Education Quality of Ukraine and $99.4 \%$ of school principals also responded positively in the survey of the MES (State Service of Education Quality of Ukraine, 2020a; Ministry of Education and Science of Ukraine, 2020a).

The majority of the surveyed students and faculty confirmed that distance learning was introduced at the level of higher education (Figure 2) (State Service of Education Quality of Ukraine, 2020b: 4). 


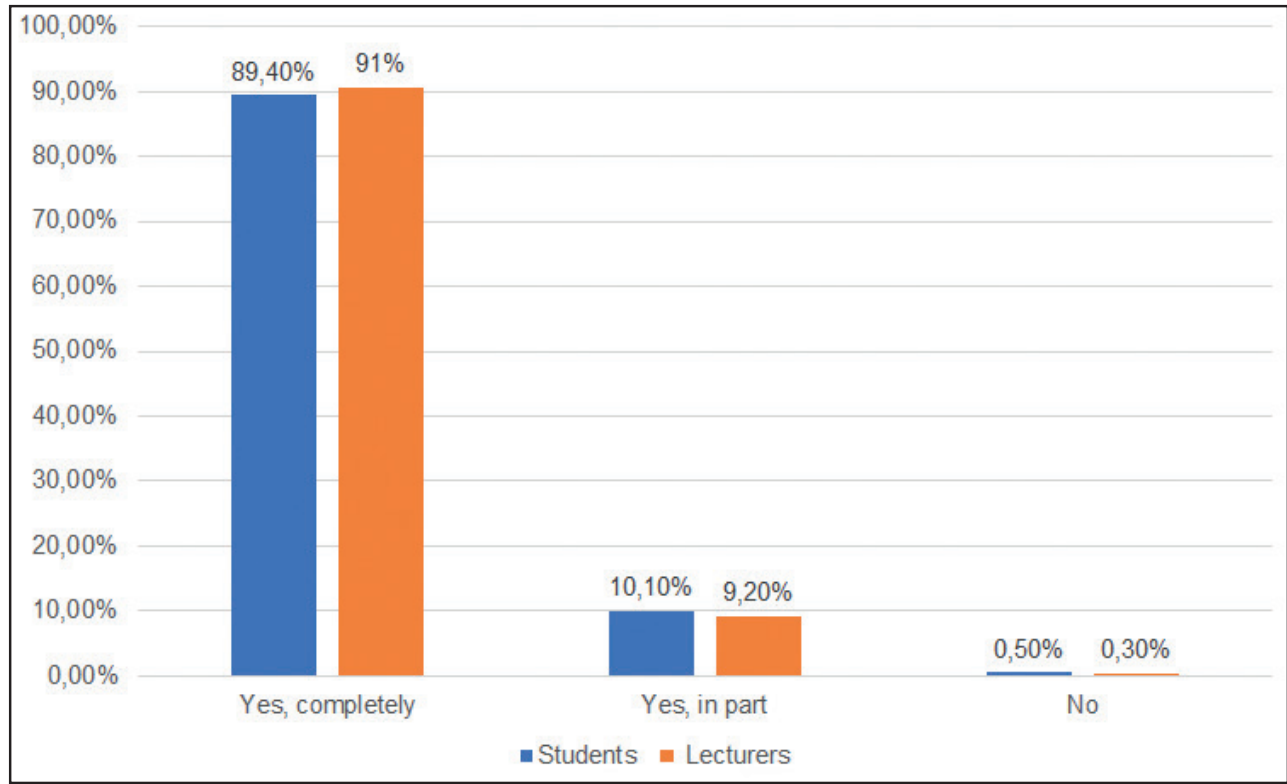

Figure 2. Percentage distribution of responses of students and lecturers to the question "Has your university managed to organise distance learning?"

To comply with the order of the MES, the most secondary schools have developed a distance learning study timetable. More than half $(56.6 \%)$ of the respondents answering the question "Did teachers of your educational institution have a study timetable for distance instruction?" said that such a timetable was developed until the end of lockdown, $35.8 \%$ said that it was developed a week or two in advance and adjusted if necessary and $7.6 \%$ said that there was no timetable at all (Ministry of Education and Science of Ukraine, 2020a: 234).

As for ISCED level 5, the responses showed that most higher education institutions left the existing before lockdown timetable unchanged. The students $(64.4 \%)$ and faculty $(71.7 \%)$ confirmed that their universities managed to ensure compliance with the timetable in the distance learning period (State Service of Education Quality of Ukraine, 2020b: 7).

The results of the analysed surveys show that Viber has become the most popular messenger while Zoom has become the most used video communication tool in Ukraine. Besides these tools, higher education institutions used such virtual learning environments as Moodle and Google Classroom. Websites of educational institutions and emails were less used. The list of tools and the degree of their use in schools from the point of view of parents is given in Figure 3 below (Educational Ombudsmen Service in Ukraine, 2020: 4). 


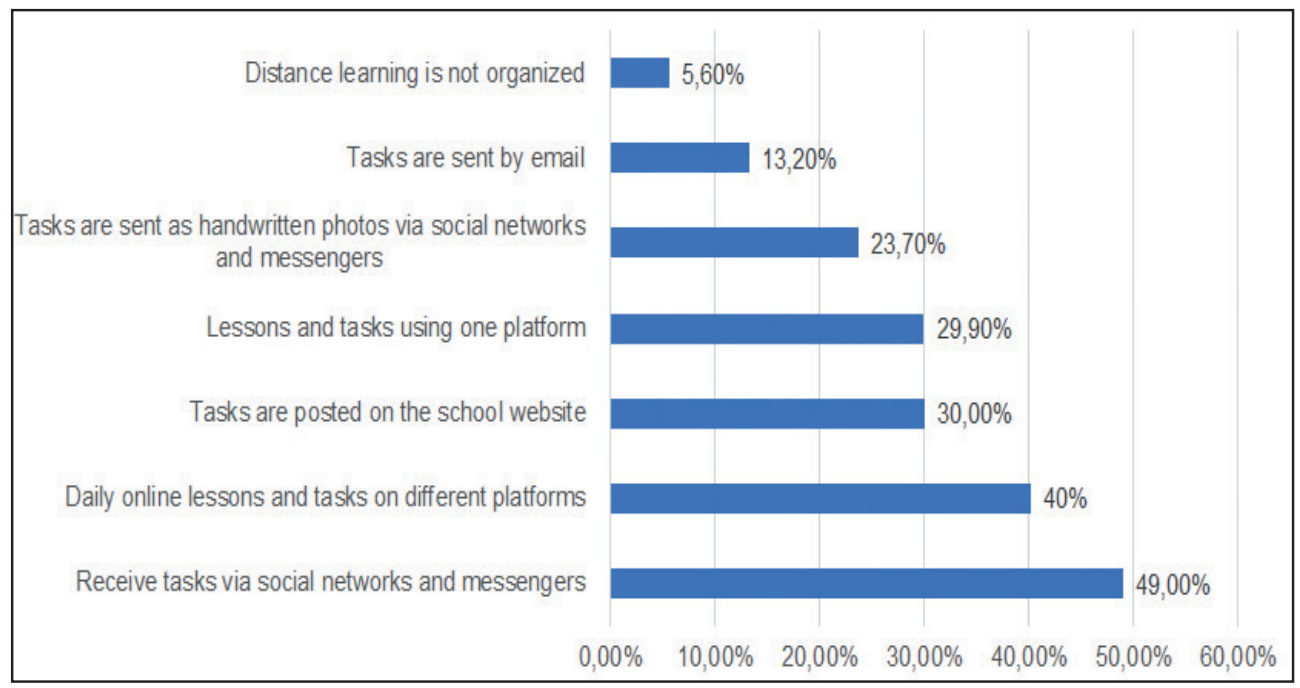

Figure 3. Percentage distribution of responses of parents to the question "What distance learning/communication tools are used in your child's school?"

School principals confirmed the opinions of parents regarding the priority of messengers for distance education (Figure 4) (Ministry of Education and Science of Ukraine, 2020a:234).

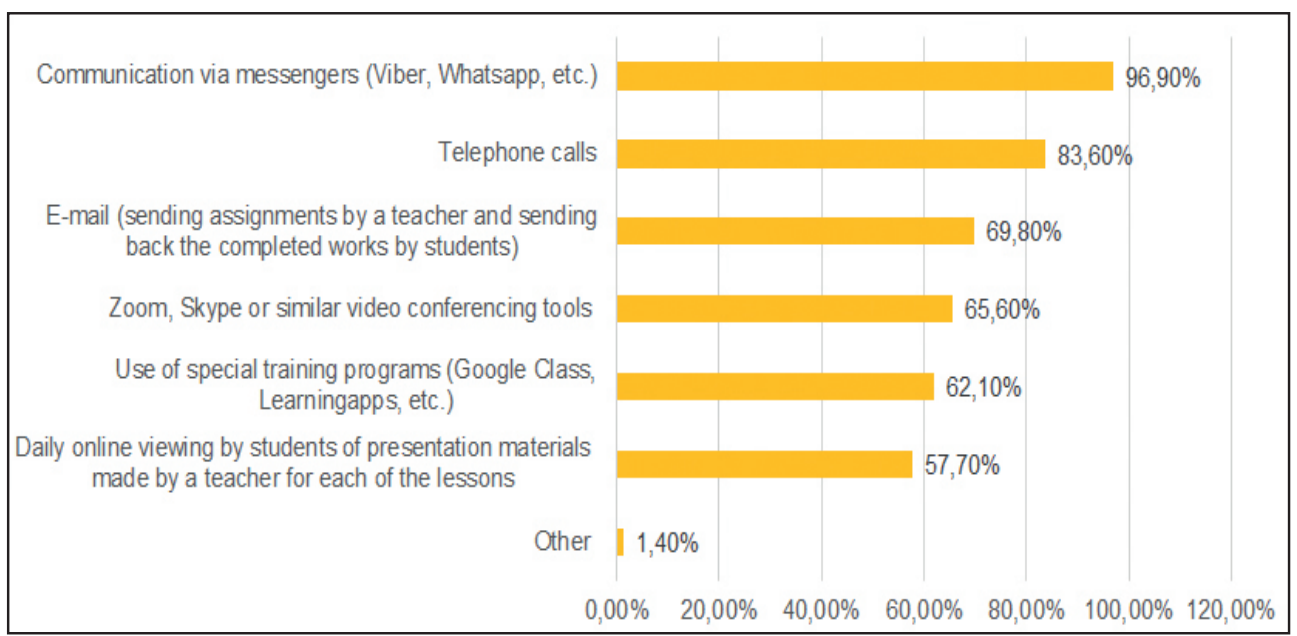

Figure 4. Percentage distribution of responses of school principals to the question "What are the channels of communication with students used by the teachers of your educational institution during distance learning?"

Secondary school teachers also responded that they constantly or periodically used the TV lessons offered by the national programme "All-Ukrainian School Online" (Ministry of Education and Science of Ukraine, 2020a).

The opinion of university educators on the distribution of distance learning tools by efficiency is generally correlated with the vision of students. However, the educators $(70.1 \%)$ 
put the use of virtual learning environments in the first place, while students (51.5\%) prefer the messengers Viber, Telegram, WhatsApp, etc. (Fig. 5) (State Service of Education Quality of Ukraine, 2020b: 7).

I do not think that the online technologies are efficient

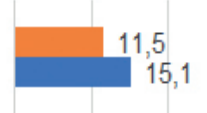

Messengers (Viber, Messenger, Telegram, WhatsUp,

Video communications (Zoom, Skype, Meet, Hangouts, etc.)

Virtual learning environments (Moodle, Google Classroom, etc.)

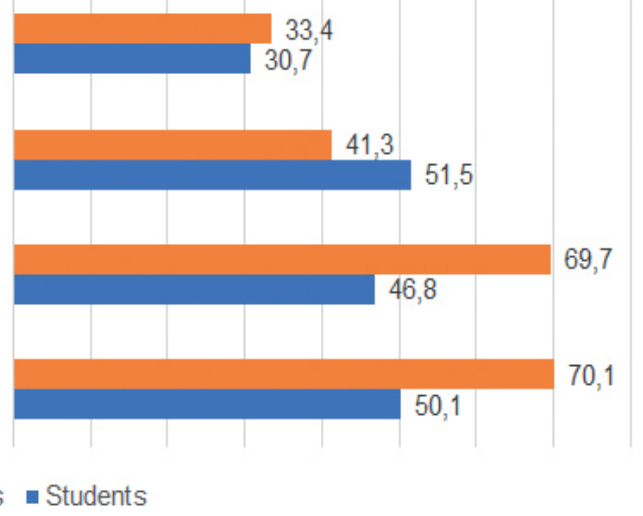

- Lecturers $\square$ Students

Figure 5. Percentage distribution of opinion of university lecturers and students relating to the efficiency of distance learning tools

The completed written assignments, which secondary school students had to send back to a teacher, were named by school principals as the most used assessment tool in their schools (Figure 6) (Ministry of Education and Science of Ukraine, 2020a).

Setting written works (dictations, assessments, etc.) followed by sending them to a teacher

Testing via online platforms

Recording video and / or audio responses by students followed by sending the responses.

Conducting oral recitations by phone

Setting written assessments (dictations, works, etc.) online

Conducting oral recitations online

Defence of projects (assessments) online

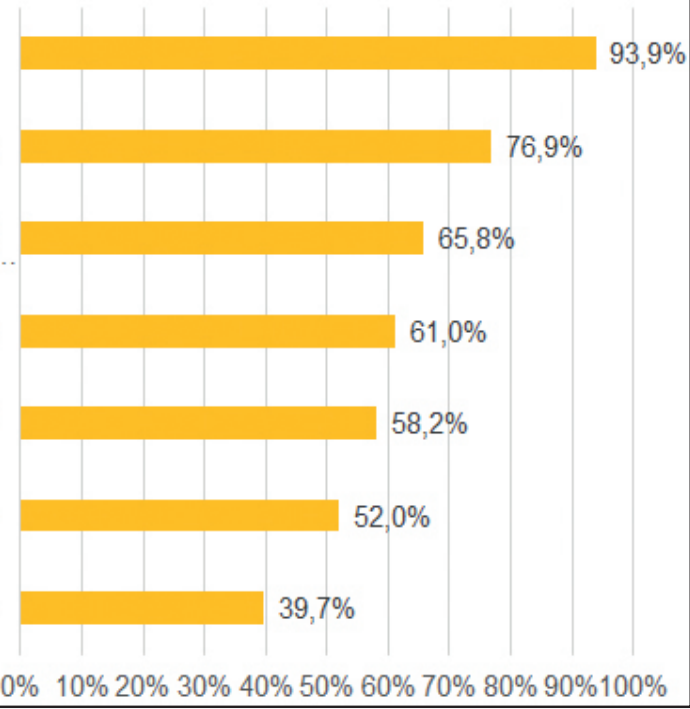

Figure 6. Percentage distribution of responses to the question "How was the assessment of academic achievements of students organised in your institution during the nationwide lockdown?" 
At the ISCED level 5, the emailing of written assignments by students was also named as the most used technology (Figure 7) (State Service of Education Quality of Ukraine, 2020b: 7).

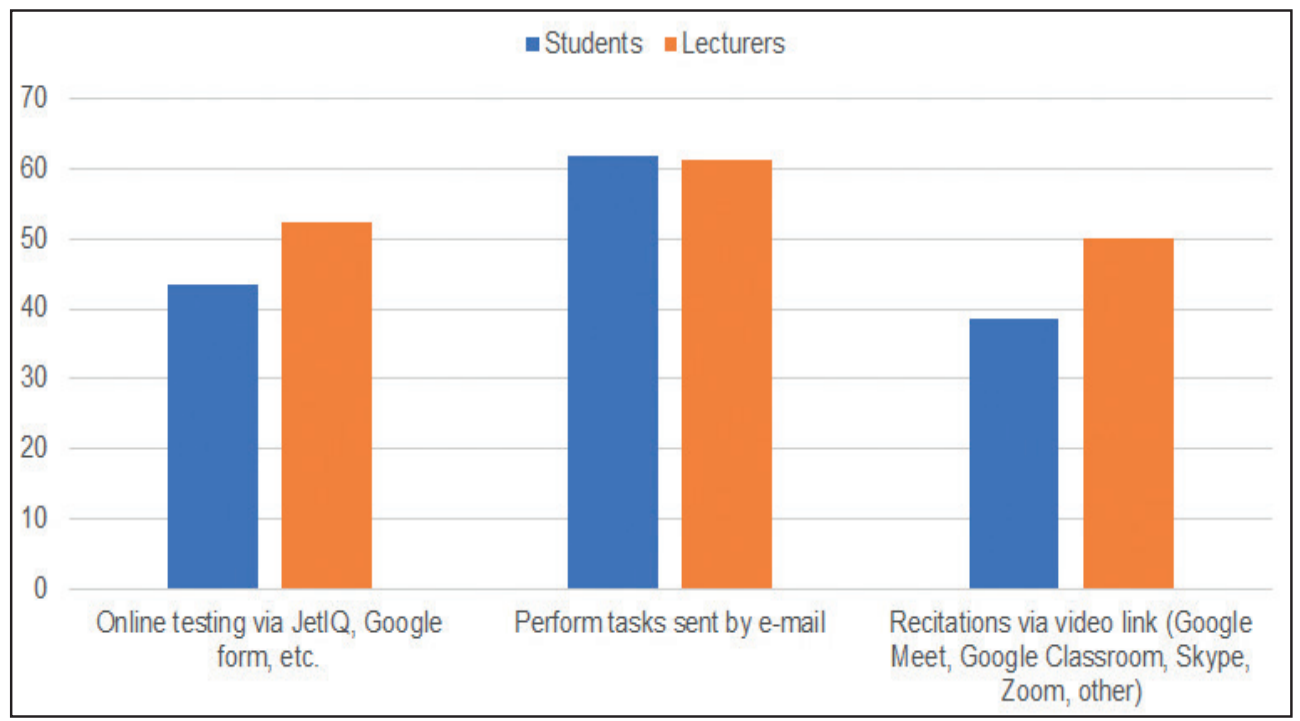

Figure 7. Percentage distribution of opinion of university lecturers and students relating usage of distance education assessment tools

Thus, the interviewed stakeholders confirmed that the distance learning was implemented in the educational institutions during the nationwide lockdown. Higher education institutions had more capabilities (technical, organisational) for it. However, the level of digital skills of educators remains a challenge affecting the level of education quality.

\subsection{The period of the adaptive lockdown of education}

In view of reducing the number of cases of the coronavirus, the Cabinet of Ministers of Ukraine by its Resolution No. 392 of 20 May 2020 replaced the nationwide lockdown with the adaptive lockdown, which by the Resolution No. 956 of 13 October 2020 extended until the end of 2020 (Cabinet of Ministers of Ukraine, 2020c; 2020d).

The Resolution No. 392 establishes that educational institutions are allowed to function without restrictions in a region (administrative-territorial unit), where the "green" and "yellow" levels of epidemic danger are established. In a region with the "orange" level of epidemic danger, class/group size is limited to 20 students. Students are forbidden to visit educational institutions in a region (administrative-territorial unit) with a "red" level of epidemic danger (Cabinet of Ministers of Ukraine, 2020c).

To regulate the functioning of education under the adaptive lockdown, the MES and the Ministry of Health have developed the following key regulations:

- Letter of the MES No. 1/9-406 of 29 July 2020 on preparation of educational institutions for the new academic year under the adaptive lockdown. The letter explains the provisions of the Resolution of the Cabinet of Ministers No. 392 on the format of functioning of educational institutions in "green", "yellow", "orange" and "red" zones (Ministry of Education and Science of Ukraine, 2020k). 
- Resolution of the Chief State Sanitary Doctor No. 42 of 30 July 2020, which approved the Provisional Recommendations on the organisation of anti-epidemic measures in educational institutions during adaptive lockdown. The recommendations contain requirements for the organisation of the educational process, feeding and transportation of students and staff. The recommendations provide mandatory temperature screening for employees at the entrance to the educational premises. The heads of educational institutions (primarily, school principals) are to make a schedule of students' admission in order to prevent crowds (Ministry of Health of Ukraine, 2020).

- Letter of the MES No.1/9-420 of 5 August 2020 "On the organization of functioning of general secondary education institutions in the 2020/2021 academic year" in which the institutions are recommended to consider the requirements of social distancing, monitoring attending school by students, informing the public health services in case of a sharp increase of COVID-19 cases, etc. (Ministry of Education and Science of Ukraine, 2020I).

- Order of the MES No. 1115 of 8 September 2020 "Some issues of distance learning". It has approved the "Regulations on Distance Learning Format of General Secondary Education". The Regulations expanded the possibilities of distance learning as a fully-fledged format of blended education (Ministry of Education and Science of Ukraine, 2020m).

Thus, the blended model of education introduced at the beginning of the 2020/2021 academic year in Ukraine is characterised by synchronisation with the local epidemiological situation, empowerment of local authorities and heads of educational institutions to make decisions on the format of the educational process and flexibility, i.e. providing various instruction options (face-to-face, blended [face-to-face + distance] and distance).

\subsection{Challenges}

It is obvious that the coronavirus has transformed the traditional model of education in Ukraine. Any transformation is always accompanied by challenges. UNESCO has identified the following global challenges accompanying the closure of educational institutions: interrupted learning; poor nutrition; confusion and stress for teachers; parents' unpreparedness for distance and home schooling; challenges in creating, maintaining and improving distance learning; gaps in childcare; high economic costs; unintended strain on health-care systems; increased pressure on schools and school systems that remain open; rise in dropout rates; increased exposure to violence and exploitation; social isolation and challenges measuring and validating learning (UNESCO, 2020b).

Similar challenges characterise Ukrainian education under "coronavirus times". These are technological, organisational, financial and social challenges. In fact, access to digital tools and the Internet have become key technological challenge (and provoked/deepened other challenges) during the nationwide education lockdown. It should be noted that this challenge is not new to Ukraine. The fact that many citizens of Ukraine do not have access to the Internet at home has been confirmed by the 2019 Ministry of Digital Transformation of Ukraine survey (Fig. 8) (Ministry of Digital Transformation of Ukraine, 2019). 


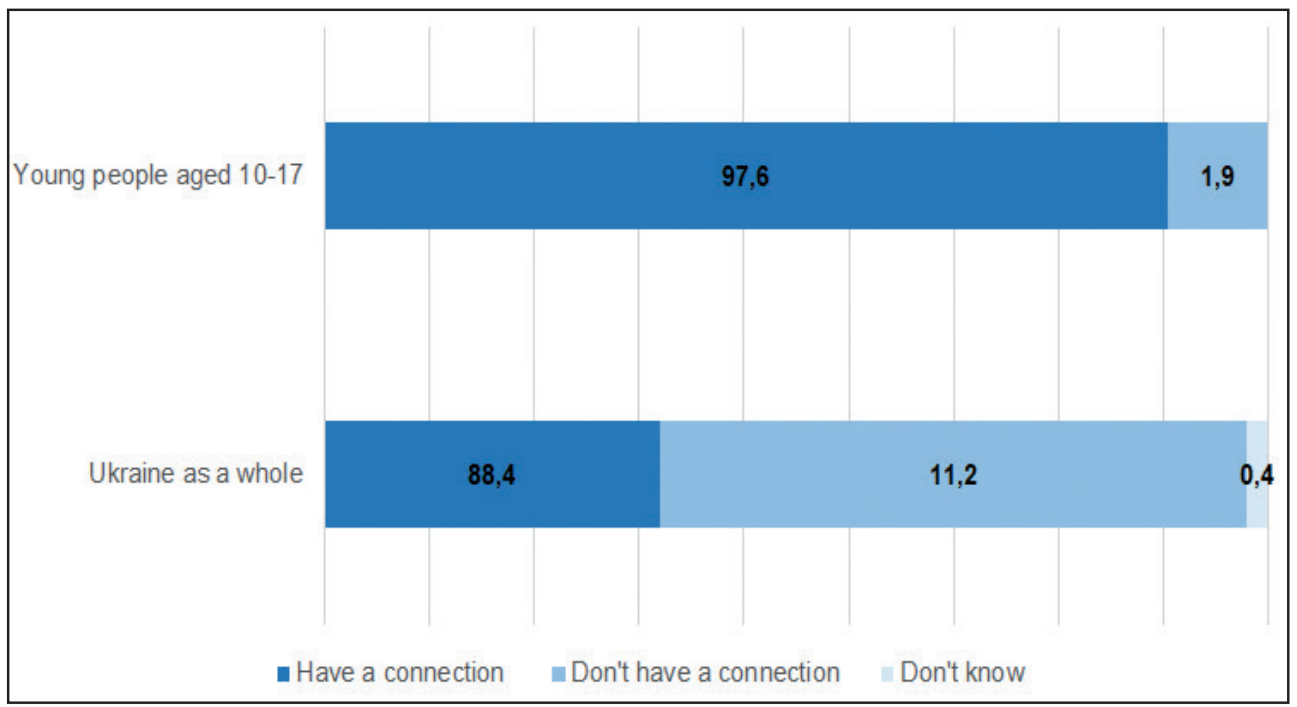

Figure 8. Percentage distribution of responses to the question "Do you have access to the Internet at home?"

The differences relating the Internet access in terms of urban and rural areas are shown in Figure 9 (Ministry of Digital Transformation of Ukraine, 2019).

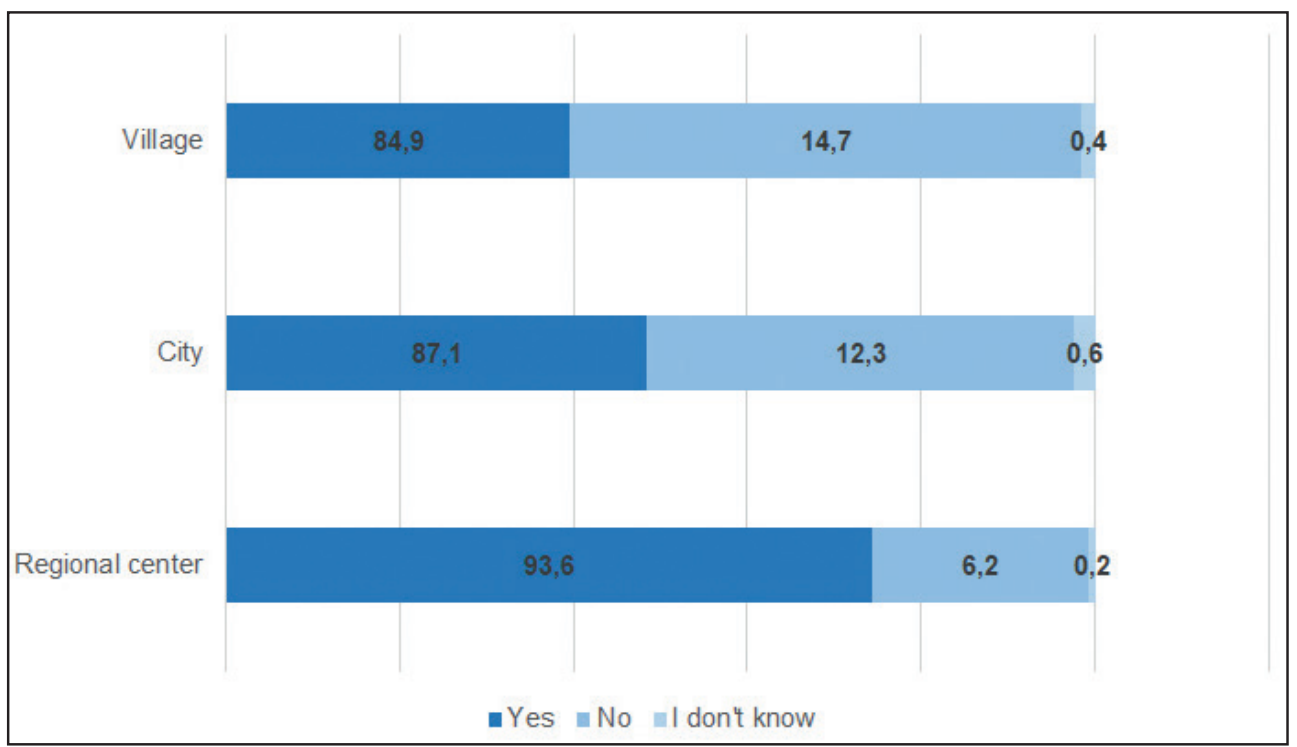

Figure 9. Percentage distribution of the responses of residents of villages, regional centres and big cities to the question "Do you have access to the Internet at home?"

No less a challenge is the availability of digital tools for distance learning. According to the survey, not all students aged 10-17 have computers at home (Figure 10) (Ministry of Digital Transformation of Ukraine, 2019). 


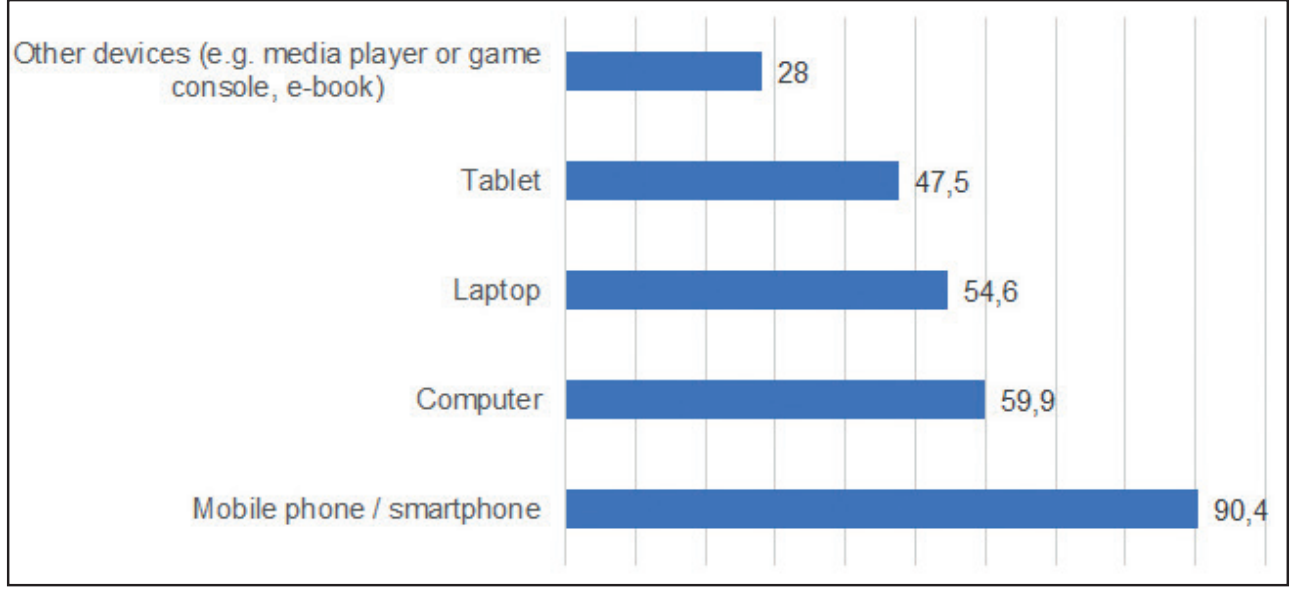

Figure 10. Percentage distribution of the responses of youth aged 10-17 "What kind of tools for Internet access do you have at home?"

The technological challenges have predictably affected the organization of distance learning under nationwide lockdown. The lack of broadband Internet and digital tools at homes of both students and teachers was confirmed by school principals (Ministry of Education and Science of Ukraine, 2020a: 231).

Technological challenges during distance learning also existed at the ISCED level 5. A large percentage $(38 \%)$ of the surveyed students faced the lack of uninterrupted access to the Internet while $23.4 \%$ of students indicated the absence of necessary digital equipment at home (State Service of Education Quality of Ukraine, 2020b: 11).

In addition to technological challenges, Ukrainian education faced numerous organisational challenges. At the time of the introduction of the nationwide lockdown in March 2020, the "Regulations on Distance Learning" approved by the MES in 2013 were in force. It is obvious that this document could not fully regulate distance learning under new realities. Besides, the Ukrainian educators did not have the experience and skills to implement the fully-fledged distance learning format. This manifested itself in the use of inefficient technologies, low methodological quality of online lessons, overloading students with homework, long stay of students in front of computer monitors, students' lack of awareness of cyber security rules, etc.

In this situation it is predicted that the distance learning model implemented during the nationwide lockdown was poorly perceived by the Ukrainian society. As of July 2020 , approximately half of the surveyed Ukrainians were negative about distance education with only $32 \%$ of citizens supporting it (Ilko Kucheriv Democratic Initiatives Foundation, 2020).

A serious organisational challenge has arisen with the beginning of the 2020/2021 academic year during the period of the adaptive lockdown. It is concerning ensuring compliance with anti-epidemic measures during the attendance of students to educational institutions. At the level of secondary education, these are the disinfection of school transport, observance of hygiene rules by students and provision of antiseptics, masks, contactless thermometers, screening at the entrance to the educational institutions, social distancing, ventilation and cleaning of premises, conducting health briefings, etc. 
This challenge is directly related to funding. The analysis of the experience of foreign countries shows that many of them (Australia, Canada, Ireland, the Netherlands, New Zeeland, Poland, Switzerland, UK, etc.) have allocated additional funding to support their education systems in the "coronavirus era". According to information from the National Center on Education and the Economy, countries:

- have allocated additional funding during the lockdown of educational institutions and after their reopening; and

- have used different approaches comprising allocation of funds for the whole education system or its levels (preschool, primary, vocational, higher); purchased digital equipment for certain groups of students (vulnerable and disadvantaged) and allocated funds to schools for providing additional instructional time for struggling students, etc. (NCEE, 2020).

Attempts are currently being made in Ukraine to obtain additional funding for education. In September 2020, the Verkhovna Rada (Parliament) of Ukraine approved a number of resolutions aimed at organising a safe educational process under the COVID-19 pandemic (Verkhovna Rada of Ukraine, 2020).

The lack of additional funding from the central budget complicates the organisation of education in the 2020/2021 academic year. The respondents provide evidence for this:

- less than half of the school principals (47.7\%) confirmed that school vehicles were disinfected and thoroughly cleaned and even fewer respondents $(44.4 \%)$ said that the vehicles were provided with antiseptics for hands;

- only $60.3 \%$ of the school principals performed screening of employees, and only $52.2 \%$ screened students before lessons;

- only $20.3 \%$ of schools can pay for additional technicians to organise proper cleaning of the premises;

- only $61.5 \%$ of school principals can provide shift visits to the school canteen and $51 \%$ ensure at least $1.5 \mathrm{~m}$ distancing between students in it. One third of the respondents confirmed that it is impossible to organise the packaging of school breakfasts/lunches in disposable containers and another third answered "probably not";

- Disinfectants for floors and surfaces as well as antiseptics for hands and paper towels are available in the range of $35-50 \%$ of the answers of the surveyed school principals. More than $35 \%$ do not have non-contact thermometers to measure body temperature.

- $42.2 \%$ of school principals answered that they could not attract additional teachers for additional division of classes/groups for financial reasons (Ministry of Education and Science of Ukraine, 2020a).

At the same time, the picture is different in each region and educational institution whose heads build their original models of organisation of education within the governmental framework. The practices of organising education in two schools in Kyiv are examples of this (Table 1). 
Table 1. Key features of the organisation of education in Kyiv schools under the adaptive lockdown

\begin{tabular}{|c|c|c|}
\hline Title & $\begin{array}{l}\text { "Gymnasium No. } 107 \\
\text { "Vvedenska" }\end{array}$ & $\begin{array}{l}\text { "Educational Complex - Lyceum No. } \\
157 "\end{array}$ \\
\hline Website & $\begin{array}{l}\text { https://www.wedenska107.com. } \\
\text { ua/ }\end{array}$ & http://lyceum157.kiev.ua/ \\
\hline Location & the city of Kyiv, Ukraine & the city of Kyiv, Ukraine \\
\hline ISCED level & Levels $1-3$ & Levels $1-3$ \\
\hline Number of students & 955 & 1525 \\
\hline Features & $\begin{array}{l}\text { The in-class model is introduced. } \\
\text { It is adaptable depending on the } \\
\text { epidemiological situation. } \\
\text { The model envisages: } \\
\text { (a) Students are taught in } \\
\text { face-to-face format if there are } \\
\text { no COVID-19 cases in their } \\
\text { classroom/school. Students stay } \\
\text { in school on the principle: "One } \\
\text { grade - one classroom". Students } \\
\text { study in one shift; in the morning } \\
\text { they enter the school through four } \\
\text { entrances to avoid the crowds. } \\
\text { (b) In case of CoVID-19 cases at } \\
\text { school, classes are divided into } \\
\text { groups that visit the school on } \\
\text { different days of the week (group } \\
\text { A - Monday, Wednesday, Friday; } \\
\text { group B - Tuesday, Thursday; } \\
\text { next week there is a change in } \\
\text { the schedule of attendance. } \\
\text { (c) In case of CovID-19 outbreak } \\
\text { in a class, distance learning } \\
\text { format is to be introduced; } \\
\text { a teacher is equipped with } \\
\text { the necessary technical tools } \\
\text { in the classroom to conduct } \\
\text { synchronous distance lessons for } \\
\text { all students. }\end{array}$ & $\begin{array}{l}\text { The blended model is introduced. } \\
\text { It is adaptable depending on the } \\
\text { epidemiological situation. The model } \\
\text { envisages: } \\
\text { (a) Division of each class into two } \\
\text { groups. } \\
\text { (b) Different start time of face-to-face } \\
\text { lessons ( } 8.00 \text { AM; } 08.15 \text { AM; } 08.30 \text { AM; } \\
\text { 12.00AM). } \\
\text { (c) Subjects that students study in class } \\
\text { in the format of traditional lessons: } \\
\text { mathematics, Ukrainian, English, } \\
\text { German, physics, chemistry, biology } \\
\text { and geography. } \\
\text { (d) Subjects that students study face-to- } \\
\text { face/remotely in joint project activities: } \\
\text { Ukrainian and foreign literature. } \\
\text { (e) Subjects that students study using } \\
\text { project technologies: physical culture, } \\
\text { labour training, health care, art and } \\
\text { computer science. } \\
\text { (f) In case of CovID-19 outbreak in } \\
\text { class, distance learning format is to } \\
\text { be introduced; a teacher is equipped } \\
\text { with the necessary technical tools in } \\
\text { the classroom to conduct synchronous } \\
\text { distance lessons for all students. }\end{array}$ \\
\hline
\end{tabular}

Both schools are the communal property of the city of Kyiv and have received additional funding from local authorities to purchase necessary materials to comply with anti-epidemic measures. The school principals have mentioned such common challenges as: insufficient level of digital skills of teachers, lack of motivation of some students to learn under new conditions, which is caused by insufficient awareness of parents about distance learning or parents' rejection of it. To meet the challenges, the principals consider it necessary to intensify cooperation with parents to encourage their engagement in their children's home-schooling; update the school's technical base and raise digital literacy of teachers. 


\section{DISCUSSION OF KEY FINDINGS}

The key overall findings from the governmental documents highlighted in this paper are that educational policy must go beyond the linearity under the COVID-19 pandemic. It is important to strengthen the regional/local/institutional levels of the education policy in order to propose the specific steps in the absence of stakeholders' experience. Evidence seems to exist that the MES promptly responded to the spread of COVID-19 by approving a number of regulatory documents while not offering specific recommendations for the implementation of the announced initiatives. The study revealed that during the period of the national lockdown, the MES approved the general provisions on the organisation of the 2019/2020 academic year. The documents emphasised the autonomy of schools in selecting forms of distance learning. However, the MES did not offer guidelines on the implementation of such forms. The letter of MES on organization of the 2020/2021 academic year provides mainly recommendation on implementation of the sanitary and hygienic standards without proposing a clear algorithm to implement the blended learning that is absolutely new for the Ukrainian education.

The study revealed that it is not just education policy that affects education under the COVID-19 pandemic. In Ukraine the technological challenges greatly influence distance learning. The problem of equal access to the Internet and the provision of digital devices to students with special needs is a matter of national significance. In fact, it concerns the societal outcomes of education (Wolhuter, 2020).

Analysis of the results of sociological surveys showed that educators in terms of technological, financial, methodological and managerial challenges are developing new formats of learning (distance and blended). The findings confirm Fullan's (2020) idea about "re-imagining" education. In this way it becomes clear that many changes are positive. This includes the long-awaited autonomy of educational institutions, the opportunity to acquire new knowledge and improve the skills of teachers, strengthening cooperation with regional and local authorities, updates of the overloaded curriculum and implementation of a competence education emphasising digital competence.

No longer can we make assumptions about the unified format of the organisation of education across all countries. Based on the findings of the interviews, it is clear that multiple institutional models of education under the pandemic exist.

\section{CONCLUSIONS}

Answering the research question "What is the educational policy under the COVID-19 pandemic in Ukraine?" we are stating that the central education authority - the MES of Ukraine - from the very beginning of the outbreak is working to adapt education to the new conditions. The approved regulations define the key parameters to govern the functioning of the education system at all levels. As a positive we note the flexibility of the educational policy, which is correlated with the epidemiological situation. The distance learning model operated during the nationwide lockdown was replaced by the blended model during the adaptive lockdown. However, the current education policy format is a response to the COVID-19 challenges. It is necessary to develop a forward-looking strategy for national education under the new conditions. The existing challenges can be seen as benchmarks for such developments.

Equal access to education during online learning is a serious challenge. The evidence provided by OECD shows that many education systems participating in PISA 2018 are not 
ready to offer most students opportunities to learn online. Reimers and Schleicher (2020) write about numerous gaps including availability of a computer for working at home, availability of the Internet and readiness of teachers to provide online instruction. In Ukraine, in addition to these challenges, there is also a gap in access to the Internet between urban and rural areas. Therefore, equal access to education should be one of the directives of the national strategy and the search for additional funding from various sources as well as the development of supportive digital environments should be key tasks. The idea of open educational resources should take precedence.

The loss of instructional time delivered in an educational institution setting requires a review of the existing practice of the education curriculum design. The class-and-lessons system that dominated for centuries no longer works, thus, Ukraine needs to look for new efficient formats and methods of instruction.

Educators' preparedness for distance learning is a priority of the educational policy. It is also important to introduce tools to motivate educators to improve their digital literacy. Equally important is the need to increase their English language proficiency to be able to use the resources of the global community.

Educational institutions are the key agents of the new model of education implementation. Answering the research question "What is the practice of organising education by educational institutions under the COVID-19 pandemic?" the obvious conclusion is that the key challenges are common to all of them. In addition to organising a blended instruction format, they must ensure compliance with anti-epidemic measures. Besides, secondary education institutions are to reach a new level of cooperation with parents to prevent students' drop-outs, establish cooperation with the private sector with the perspective of additional funding and strengthening cooperation with the community, thus jointly combating the effects of social isolation of students and their families. Obviously, each institution develops its own model within the current legislation and depending on local conditions. The issue of the implementation of state standards acquires special significance. In this context, the quality assurance of education becomes a national challenge.

Ukraine is in search of efficient tools to develop national education under the COVID-19 pandemic. The lack of possibility of their scientific substantiation and piloting makes this task much more difficult. The way out is the maximum openness and cooperation with the world educational community.

\section{REFERENCES}

Benecke, G., Schurink, W. \& Roodt, G. 2007. Towards a substantive theory of synergy. South African Journal of Human Resource Management, 5(2): 9-19. https://doi.org/10.4102/sajhrm. v5i2.115.

Collins Dictionary. 2020. Synergy. Available at https://www.collinsdictionary.com/dictionary/ english/synergy [Accessed 6 November 2020].

Educational Ombudsman Service in Ukraine. 2020. Rezultaty opytuvannia batkiv Navchannia ditei pid chas karantynu [Parent Survey Results Teaching children during quarantine"]. Available at https://eo.gov.ua/wp-content/uploads/2020/04/Rezul-taty-opytuvannia-22Navchanniaditey-pid-chas-karantynu22.pdf [Accessed 1 November 2020]. (in Ukrainian). 
Daniel, S.J. 2020. Education and the COVID-19 pandemic. Prospects, 49(1-2): 91-96. https:// doi.org/10.1007/s11125-020-09464-3.

Fullan, M. 2020. Learning and the pandemic: What's next? Prospects, 49(1-2): 25-28. https:// doi.org/10.1007/s11125-020-09502-0.

Haken, H. 1983. Introduction. In H. Haken. Advanced synergetics (pp. 1-60). Berlin: Springer. https://doi.org/10.1007/978-3-642-45553-7_1.

Hrynevych, L., Ilich, L., Morze, N., Proshkin, V., Shemelynets, I., Lynov, K. \& Rii, H. 2020. Orhanizatsiia osvitnoho protsesu $v$ shkolakh Ukrainy $v$ umovakh karantynu: analitychna zapyska [Organization of the educational process in Ukrainian schools under quarantine: an analytical note. Available from https://www.irf.ua/wp-content/uploads/2020/09/organizacziyaosvitnogo-proczesu-v-shkolah-ukrayiny-v-umovah-karantynu-2020.pdf [Accessed 1 November 2020].

Ilko Kucheriv Democratic Initiatives Foundation. 2020. Osvita i pandemiia: shcho ukraintsi dumaiut pro dystantsiine navchannia ta yak otsiniuiut ZNO [Education and pandemic: what Ukrainians think about distance learning and how they evaluate External Independent Assessment]. Available from https://dif.org.ua/article/osvita-i-pandemiya-shcho-ukraintsidumayut-pro-distantsiyne-navchannya-ta-yak-otsinyuyut-zno [Accessed 1 November 2020].

Kremen, V. 2013. Pedahohichna synerhetyka: poniatiino-katehorialnyi syntez [Pedagogical synergetics: conceptual categorical synthesis]. Filosofiia osvity, 3: 3-19. (in Ukrainian).

Lokshyna, O.I., Glushko O.Z., Dzhurylo, A.P., Kravchenko, S.M., Nikolska, N.V., Tymenko, M.M. \& Shparyk, O.M. 2020. Vidpovid svitovoi spilnoty na vyklyky COVID-19 v osviti (liutyicherven 2020 r.): ohliadove vydannia [The response of the world community to the challenges of COVID-19 in education (February-June 2020). https://doi.org/10.32405/978-966-97763-04-2020-36. (in Ukrainian).

Merriam-Webster. 2020. Synergy. Available at https://www.merriam-webster.com/dictionary/ synergy [Accessed November 2, 2020].

NCEE. 2020. Archive: International Education News. Available at https://ncee.org/what-we-do/ center-on-international-education-benchmarking/international-ed-news-archive/ [Accessed 28 October 2020].

Reimers, F.M. \& Schleicher, A. 2020. A framework to guide an education response to the COVID-19Pandemic of 2020. Availableathttps://read.oecd-ilibrary.org/view/?ref=126_126988t63lxosohs\&title=A-framework-to-guide-an-education-response-to-the-Covid-19-Pandemicof-2020 [Accessed 2 November 2020].

State Service of Education Quality of Ukraine. 2020. Analitychna dovidka shchodo orhanizatsii dystantsiinoho navchannia u zakladakh zahalnoi serednoi osvity $v$ umovakh karantynu [Analytical information on the organization of distance learning in general secondary education under the quarantine]. Available at http://www.sqe.gov.ua/images/

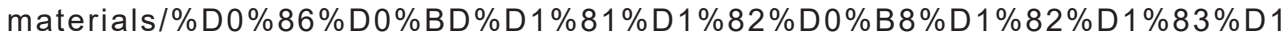
\% 86\%D1\%96\%D0\%B9\%D0\%BD\%D0\%B8\%D0\%B9\%20\%D0\%B0\%D1\% 83\%D0 \%B4\%D0\%B8\%D1\%82/28.05.2020 \%D0\%90\%D0\%BD\%D0\%B0\%D0\%BB\%D1\% $96 \%$ D $1 \% 82 \%$ D0 \%B8\%D1\%87\%D0\%BD\%D0\%B0 \%D0\%B4\%D0\%BE\%D0\%B2\%

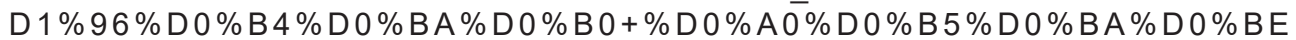

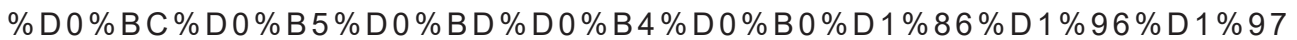
\%D0\%BE\%D0\%BF\%D0\%B8\%D1\%82\%D1\%83\%D0\%B2\%D0\%B0\%D0\%BD\%D0\%BD\% D1\%8F_\%D0\%94\%D0\%98\%D0\%A1 \%D0\%A2\%D0\%90\%D0\%9D\%D0\%A6\%D0\%86\%D0 
\%99\%D0\%9D\%D0\%95-\%D1\%88\%D0\%BA\%D0\%BE\%D0\%BB\% D0\%B0.pdf [Accessed 28 October 2020]. (in Ukrainian).

State Service of Education Quality of Ukraine. 2020b. Informatsiino-analitychna dovidka pro rezultaty opytuvannia shchodo stanu vykorystannia tekhnolohii dystantsiinoho navchannia u zakladakh vyshchoi osvity Ukrainy [Information and analytical information on the results of a survey on the state of use of distance learning technologies in higher education institutions of Ukraine]. Available at http://www.sqe.gov.ua/images/materials/\%D0\% BE \%D0\%BF\%D0\%B8\%D1\%82\%D1\%83\%D0\%B2\%D0\%B0\%D0\%BD\%D0\%BD\% D1\%8F/\%D0\%B7\%D0\%B2\%D0\%BE/\%D0\%9E\%D0\%BF\%D0\%B8\%D1\%82\%D1\%83 \%D0\%B2\%D0\%B0\%D0\%BD\%D0\%BD\%D1\%8F_\%D0\%B4\%D0\%B8\%D1\%81\%D1\% 82\%D0\%B0\%D0\%BD\%D1\%86\%D1\%96\%D0\%B9\%D0\%BD\%D0\%B5\%20\%D0\%BD\%D0\% B0\%D0\%B2\%D1\%87\%D0\%B0\%D0\%BD\%D0\%BD\%D1\%8F_\%D0\%97\%D0\%92\%D0\% 9E.pdf [Accessed 28 October 2020]. (in Ukrainian).

Tadesse, S. \& Muluye, W. 2020. The Impact of COVID-19 pandemic on education system in developing countries. A Review. Open Journal of Social Sciences, 8: 159-170. https://doi. org/10.4236/jss.2020.810011

Ukraine. Cabinet of Ministers of Ukraine. 2020a. Postanova № 211 vid 11 bereznia 2020 r. «Pro zapobihannia poshyrenniu na terytorii Ukrainy koronavirusu COVID-19» [Resolution No. 211 of March 11, 2020 "On prevention of the spread of coronavirus COVID-19 on the territory of Ukraine"].Available athttps://www.kmu.gov.ua/npas/pro-zapobigannya-poshim110320rennyuna-teritoriyi-ukrayini-koronavirusu-covid-19 [Accessed 8 October 2020].

Ukraine. Cabinet of Ministers of Ukraine. 2020b. Postanova № 641 vid 22 lypnia 2020 r. «Pro vstanovlennia karantynu ta zaprovadzhennia posylenykh protyepidemichnykh zakhodiv na terytorii iz znachnym poshyrenniam hostroi respiratornoi khvoroby COVID-19, sprychynenoi koronavirusom SARS-CoV-2» [Resolution No. 641 of July 22, 2020 "On the establishment of quarantine and the introduction of enhanced anti-epidemic measures in the area with a significant spread of acute respiratory disease COVID-19 caused by coronavirus SARSCoV-2"]. Available at https://www.kmu.gov.ua/npas/pro-vstanovlennya-karantinu-ta-zapr-641 [Accessed 8 October 2020].

Ukraine. Cabinet of Ministers of Ukraine. 2020c. Postanova № 392 vid 20 travnia 2020 r. «Pro vstanovlennia karantynu z metoiu zapobihannia poshyrenniu na terytorii Ukrainy hostroi respiratornoi khvoroby COVID-19, sprychynenoi koronavirusom SARS-CoV-2, ta etapiv poslablennia protyepidemichnykh zakhodiv» [Resolution No. 392 of May 20, 2020 "On the establishment of quarantine in order to prevent the spread of acute respiratory disease COVID-19 in Ukraine caused by the coronavirus SARS-CoV-2, and the stages of mitigation of anti-epidemic measures»]. Available at https://www.kmu.gov.ua/npas/pro-vstanovlennyakarantinu-z-metoyu-zapobigannya-poshirennyu-na-teritoriyi-ukrayini-gostroyi-respiratornoyihvorobi-covid-19-sprichinenoyi-koronavirusom-sars-cov-i200520-392 [Accessed 6 November 2020]. (in Ukrainian).

Ukraine. Cabinet of Ministers of Ukraine. 2020d. Postanova № 956 vid 13 zhovtnia 2020 r. «Pro vnesennia zmin do Postanovy Kabinetu Ministriv Ukrainy № 641 vid 22 lypnia 2020 r.» [Resolution No. 956 of October 13, 2020 On amendments to the Resolution of the Cabinet of Ministers of Ukraine No. 641 of July 22, 2020]. Available at https://www.kmu.gov.ua/ npas/pro-vnesennya-zmin-do-postanovi-kabinetu-ministriv-ukrayini-vid-22-lipnya-2020-r641-i131020-956 [Accessed 6 November 2020].

Ukraine. Ministry of Digital Transformation of Ukraine. 2019. Tsyfrova hramotnist naselennia Ukrainy [Digital Literacy of the Population of Ukraine]. Available at https://osvita.diia.gov.ua/ 
uploads/0/585-cifrova_gramotnist_naselenna_ukraini_2019_compressed.pdf [[Accessed 22 October 2020].

Ukraine. Ministry of Education and Science of Ukraine. 2020a. Osvita v Ukraini: vyklyky ta perspektyvy. Informatsiino-analitychnyi zbirnyk [Education in Ukraine: challenges and prospects. Information-analytical collection]. Available at https://mon.gov.ua/storage/app/ media/zagalna\%20serednya/serpneva-konferencia/2020/metod-zbirka-osvita-ta-covid-2020. pdf [[Accessed 3 November 2020].

Ukraine. Ministry of Education and Science of Ukraine. 2020b. Lyst MON Ukrainy №1/9-154 vid 11 bereznia 2020 r. [Letter of the MES No. 1/9154 of March 11, 2020]. Available at https://mon.gov.ua/storage/app /media/ news/\%D0\%9D\%D0\%BE\%D0\%B2\%D0\%B8\%D0\%BD\%D0\%B8/2020/03/11 /1_9154.pdf [[Accessed 4 November 2020].

Ukraine. Ministry of Education and Science of Ukraine. 2020c. Nakaz MON Ukrainy № 392 vid 12 bereznia 2020 r. «Pro zabezpechennia vykonannia profilaktychnykh ta protyepidemichnykh zakhodiv» [Order of the MES No. 392 of March 12, 2020 "On ensuring the implementation of preventive and anti-epidemic measures"]. Available at https://osvita.ua/legislation/ other/71600/ [[Accessed 1 November 2020].

Ukraine. Ministry of Education and Science of Ukraine. 2020d. Lyst MON Ukrainy №1 / 9-161 vid 13 bereznia 2020 r. «Pro orhanizatsiiu oplaty pratsi pratsivnykiv navchalnykh zakladiv cherez karantyn» [Letter of the MES No.1/9-161 of March 13, 2020 "On the organization of remuneration of employees of educational institutions during COVID-19 lockdown"]. Available at https://mon.gov.ua/storage/app/media/13.03.2020/1_9-161.pdf [[Accessed 1 November 2020].

Ukraine. Ministry of Education and Science of Ukraine. 2020e. Nakaz MON Ukrainy № 406 vid 16 bereznia 2020 r. "Pro orhanizatsiini zakhody shchodo zapobihannia rozshyrenniu COVID-19» [Order of the MES No. 406 of March 16, 2020 "On organizational measures to prevent the expansion of COVID-19"]. Available at https://mon.gov.ua/ua/npa/proorganizacijni-zahodi-dlya-zapobigannya-poshirennyu-koronavirusu-s-ovid-19 [Accessed 3 November 2020].

Ukraine. Ministry of Education and Science of Ukraine. 2020f. Lyst MON №1 / 9-161 vid 13 bereznia 2020 r. «Pro orhanizatsiiu oplaty pratsi pratsivnykiv navchalnykh zakladiv cherez karantyn» [Letter of the MES No.1/9-161 of March 13, 2020 "On the organization of remuneration of employees of educational institutions during COVID-19 lockdown"]. Available at https:// mon.gov.ua/storage/app/media/13.03.2020/1_9-161.pdf [Accessed 4 November 2020].

Ukraine. Ministry of Education and Science of Ukraine. 2020g. Lyst MON Ukrainy №1 / 9-176 vid 25 bereznia 2020 r. «Shchodo osoblyvostei orhanizatsii osvitnoho protsesu pid chas karantynu» [Letter of the MES No. 1/9-176 of March 25, 2020 "On the features of the organization of the educational process during quarantine"]. Available from https://mon.gov. ua/ua/npa/shodo-osoblivostej-organizaciyi-osvitnogo-procesu-pid-chas-karantinu [Accessed 2 November 2020].

Ukraine. Ministry of Education and Science of Ukraine. 2020h. Lyst MON Ukrainy №1 / 9-177 vid 26 bereznia 2020 r. «Shchodo orhanizatsii osvitnoho protsesu v zakladakh profesiinoi (profesiino-tekhnichnoi) osvity na period karantynu» [Letter of the MES No. 1/9-177 of March 26, 2020 "On the organization of the educational process in vocational (vocational and technical) educational institutions during lockdown"]. Available at https://mon.gov.ua/ua/npa/ 
shodo-organizaciyi-osvitnogo-procesu-v-zakladah-profesijnoyi-profesijno-tehnichnoyi-osvitina-period-karantinu [Accessed 2 November 2020].

Ukraine. Ministry of Education and Science of Ukraine. 2020i. Lyst MON Ukrainy №1/9-178 vid 27 bereznia 2020 r. «Shchodo zavershennia 2019/2020 navchalnoho roku» [Letter of the MES No. 1/9-178 of March 27, 2020 "On the ending the 2019/2020 academic year"]. Available from https://mon.gov.ua/ua/npa/shodo-zavershennya-201920-navchalnogo-roku [Accessed 2 November 2020].

Ukraine. Ministry of Education and Science of Ukraine. 2020j. Vchymo i navchaiemos na karantyni: zminy v systemi osvity [Teaching and Learning under Quarantine: Changes in the Education System]. Available at http://mon-covid19.info [Accessed 3 October 2020].

Ukraine. Ministry of Education and Science of Ukraine. 2020k. Lyst MON Ukrainy №1/9-406 vid 29 lypnia 2020 r. «Pro pidhotovku navchalnykh zakladiv do novoho navchalnoho roku ta opaliuvalnoho sezonu v umovakh adaptyvnoho karantynu» [Letter of the MES No. 1/9-406 of July 29, 2020 "On preparation of educational institutions for the new academic year and heating season under the adaptive quarantine"]. Available at https://mon.gov.ua/storage/app/ media/civilniy-zahist/2020/07/30/1_9-406.pdf [Accessed 5 November 2020].

Ukraine. Ministry of Education and Science of Ukraine. 2020I. Lyst MON Ukrainy №1/9-420 vid 5 serpnia 2020 r. «Shchodo orhanizatsii roboty zakladiv zahalnoi serednoi osvity u 2020/2021 navchalnomu rotsi» [Letter of the MES No. 1/9-420 of August 5, 2020 "On the organization of functioning of general secondary education institutions in the 2020/2021 academic year"]. Available at https://osvita.ua/legislation/Ser_osv/75559/ [Accessed 5 November 2020].

Ukraine. Ministry of Education and Science of Ukraine. 2020m. Nakaz MON Ukrainy №1115 vid 8 veresnia $2020 \mathrm{r}$. «Deiaki pytannia orhanizatsii dystantsiinoho navchannia» [Order of the MES No. 1115 of September 8, 2020 "Some issues of distance learning"]. Available at https:// zakon.rada.gov.ua/laws/show/z0941-20\#Text [Accessed 2 November 2020].

Ukraine. Ministry of Health of Ukraine. 2020. Postanova holovnoho derzhavnoho sanitarnoho likaria Ukrainy № 42 vid 30 lypnia 2020 r. «Pro zatverdzhennia tymchasovykh rekomendatsii shchodo orhanizatsii protyepidemichnykh zakhodiv u zakladakh osvity v period karantynu v zviazku z poshyrenniam koronavirusnoi khvoroby (COVID-19)» [Resolution of the Chief State Sanitary Doctor No. 42 of July 30, 2020 "On approval of provisional recommendations on the organization of anti-epidemic measures in educational institutions during the quarantine period in connection with the spread of coronavirus disease (COVID-19)"]. Available at https://moz.gov.ua/uploads/ckeditor/\%D0\%B4\%D0\%

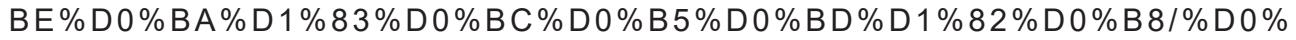
$93 \%$ D 0 \% BE \% D 0 B B \% D 0 BE \% D 0 B 2\% D 0 BD \% D 0 B 8 \% D 0 B B \% 20

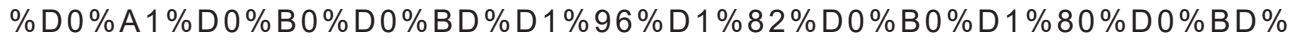

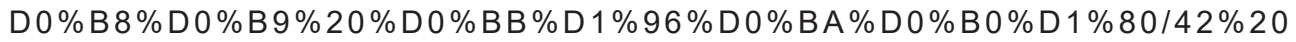
\%D1\%88\%D0\%BA\%D0\%BE\%D0\% BB\%D0\% B8.pdf [Accessed 3 November 2020].

Ukraine. Verkhovna Rada of Ukraine. 2020. Proekt № 4057 vid 7 veresnia 2020 «Postanovy pro zvernennia do Kabinetu Ministriv Ukrainy shchodo vzhyttia nevidkladnykh zakhodiv dlia zabezpechennia bezpechnoho navchalnoho protsesu i yakisnoi osvity $v$ umovakh karantynu zaprovadzhenoho z metoiu zapobihannia poshyrenniu na terytorii Ukrainy hostroi respiratornoi khvoroby COVID-19, sprychynenoi koronavirusom SARS-CoV-2» [Project No. 4057 of September 7, 2020 "Resolutions on appealing to the Cabinet of Ministers of Ukraine to take urgent measures to ensure a safe educational process and quality education in the conditions of quarantine introduced to prevent the spread of acute respiratory disease 
COVID-19 caused by Coronavirus SARS"]. Available at http://w1.c1.rada.gov.ua/pls/zweb2/ webproc4_1?pf3511=69854 [Accessed 5 November 2020].

UNESCO. 2020a. COVID-19 educational disruption and response. Available at https://en.unesco.org/news/covid-19-educational-disruption-and-response [Accessed 26 October 2020].

UNESCO. 2020b. COVID-19 Adverse consequences of school closures. Available at https:// en.unesco.org/covid19/educationresponse/consequences [Accessed 26 October 2020].

UNESCO. 2020c. COVID-19 Distance learning solutions. Available at https://en.unesco.org/ covid19/educationresponse/solutions [Accessed 27 October 2020].

World Health Organization (WHO). 2020. WHO Coronavirus Disease (COVID-19) Dashboard. Available at https://covid19.who.int/ [Accessed 2 November 2020].

Wolhuter, C. 2020. Covid-19: A ray of lightning for comparative and international education? Journal of Contemporary Educational Studies/Sodobna Pedagogika, 4(71): 190--204. 